\title{
The Crisis of Identity in Africa: A Call for Subjectivity
}

Thomas Kochalumchuvattil

\section{Introduction}

The humanitarian problems of Africa are manifest and widespread. Periodic occurrences of ethnic cleansing as seen in Rwanda, the ongoing conflict in Darfur-Sudan, the breakdown of democracy under the dictatorship of President Robert Mugabe in Zimbabwe, the outbreak of postelection violence in Kenya, the widespread growth of HIV/AIDS and overwhelming endemic poverty are by no means isolated examples of the tragedies which continue to plague the continent. These and similar issues have become the subject of intense philosophical debate and reflection. This contribution to the debate will argue that if a sustainable solution to all of these problems is to be found the key area requiring philosophical debate is the degree to which the subjective development of the self is submerged in an African sense of collective identity.

The first section of this article points to the African crisis in identity and considers the role of the Ubuntu philosophy in the recovery of the African identity and self respect while at the same time arguing that it is insufficient in itself to consistently bring about the growth of freedom and responsibility that are the marks of true personhood. It is argued that this lack of individuation is at the root of the African crisis in identity and in the failure of the continent to sufficiently address its problems. The prevalence of communalism in African society is identified as the main barrier to the process of subjective becoming. This argument is developed in the second section where communalism is presented as being rooted in the African's cosmic vision. In the third section, one finds that the lack of recognition of self-hood is attributed to the excessive objectification or over-determination of the cultural community.

The fourth section briefly introduces Kierkegaard's call for subjectivity as a guiding framework to overcome oppressive communalism in the African situation. This argument is further developed in the fifth section where it shown that Kierkegaard's call for subjectivity is essential for the emergence of the personhood necessary to make the intersubjectivity at the heart of African Philosophy in general, and Ubuntu in particular, an authentic reality. The sixth section finally makes use of the five African principles of Nguzo Tano in order to map out the path of subjectivity in the African context. 


\section{The Question of Self-identity and the Philosophy of Ubuntu}

The search for identity has always been a key issue facing mankind in its striving after significance and meaning. However the African understanding of self is in crisis having been assailed from a number of directions. The female Kenyan 2004 Nobel Peace Laureate, environmental activist and writer Wangari Maathai opines that if Africa is to build for the future it must first face its past. The book shows Africa's colonial history as a disastrous period for the continent and how many of the problems faced by its people today stem from that past. It tells of Africa's loss of identity under its colonial occupiers and the disintegration of societal hierarchies that had developed over centuries. The resulting crisis of leadership, corruption and a reluctance to relinquish power has stunted development. Puppet governments, the exploitation of the continent's abundant natural resources and the use of African nations as a buffer against eastern communism or western capitalism have, for Maathai, left Africa both physically and psychologically scarred. ${ }^{1}$

The Historical Overview of the Berlin - Congo Conference in 1884-85 and its consequences found in Part 1 of the Report on the Reconciliation Conference Africa - Europe which took place in Ambilly, France 29-31 October 2002 took a similar view of the consequences of colonialism. The report concluded that aside from, "a loss of identity," and "distrust in African national and regional and tribal identities," along with economic impoverishment there exists a, "lack of love in Africa" along with "wars, genocide, ethnic conflicts." The report goes on to say that, "Africans tend to remain in a victim role, which is easier than taking responsibility for their own sins and hatred."2

Historically, Africa may have lagged behind Europe in terms of technology. However, long before the coming of Europeans to the continent Africans possessed social and political philosophies as valid as those of their European counterparts. These systems revolved around a universal recognition of human worth which formed the spiritual foundation of African societies. The name given to the underlying philosophy is Ubuntu (a Zulu word). It is a unifying vision or worldview inspired by the Zulu maxim, "umuntu ngumuntu ngabantu (a person is a person through other persons). ${ }^{3}$ The philosophy of Ubuntu (humanness) in recent times has gained significant attention in African philosophical discourse especially due to the political developments in South Africa and the call made by President Thabo Mbeki for

\footnotetext{
1 Wangari Maathai, The Challenge for Africa: A New Vision (London: William Heinemann, 2009), 4-5.

2 Part 1 of the Report on the Reconciliation Conference Africa-Europe, Ambilly, France 29-31 October 2002, <http://www.servingthenations.org/article.asp?ArticleID=15>, 29 September 2009. 46.

${ }^{3}$ Augustine Shutte, Philosophy for Africa (Rondebosch, South Africa: UCT Press, 1993),
} 


\section{0}

THE CRISIS OF IDENTITY IN AFRICA

an "African Renaissance."4 The search for an African philosophical explanation of the experience gained under the Truth and Reconciliation Commission (TRC) has also accelerated intellectual interest in this emerging philosophy. According to Ubuntu, there exists a common bond between all human beings and it is through this bond and through our interaction with our fellow human beings that we discover our own human qualities. The South African Nobel Laureate Archbishop Desmond Tutu describes Ubuntu in this way:

Africans have this thing called UBUNTU ... the essence of being human. It is part of the gift that Africans will give the world. It embraces hospitality, caring about others, willing to go the extra mile for the sake of others. We believe a person is person through another person that my humanity is caught up, bound up and inextricable in yours. When I dehumanize you I inexorably dehumanize myself. The solitary individual is a contradiction in terms and, therefore, you seek to work for the common good because your humanity comes into its own community, in belonging. ${ }^{5}$

In many ways Ubuntu philosophy finds a unique position between the objective and subjective approaches to identity. This is very well expressed by Dion Foster:

... if one were to apply the dialogical conceptual framework of I - Thou developed by Martin Buber in his philosophical essay Ich un $D u$ (1923), one would be able to show that in the African worldview it is neither the ' $\mathrm{I}$ ' (individual) nor the 'Thou' (community) that takes ontological primacy. Rather the ontological primacy is focussed on the hyphen, the 'between', of the I - Thou. ${ }^{6}$

${ }^{4}$ However, it is to be pointed out here as Tejada has argued that Ubuntu philosophy is practiced by Africans in most parts of the continent, especially in those regions stretching "from the Nubian desert to the Cape of Good Hope and from Senegal to Zanzibar." But Ramose is of the view that this geographical delimitation is problematic since it creates a barrier of the desert to be an Africa's birthmark and therefore obscuring the meaning and import of human interaction on the continent before the desert crept in. In order to fully understand the essence and significance of the philosophy, one has therefore to approach the subject historically and comprehensively. See, Mogobe B. Ramose, African Pbilosophy Through Ubuntu (Harare: Mond Books, 1999), 50. Cheick Anta Diop has traced the generic term for man or ntu, to be the same on other African languages with similar term nit in Wolf, nti in Egyptian, and neddo in Peul. He argues that the designation of a people by a generic term meaning man has been general throughout Black Africa, starting with Egypt. See, Cheick Anta Diop, The African Origin of Civilization (Chicago: Lawrence Hill Books, 1974), 198.

5 Desmond Tutu, No Future without Forgiveness: A Personal Overview of South Africa's Truth and Reconciliation Commission (London: Doubleday Publishers, 1999), 22.

${ }^{6}$ Dion Forster, The impact of knowledge systems on buman development in Africa (Pretoria: University of South Africa, 2007), 261. 
Expressed in another way, Ubuntu philosophy is neither objective nor subjective. Rather it lies between the two and is often talked about in terms of intersubjectivity. However, despite the great attention paid to the philosophy of Ubuntu, it is not without its difficulties and critics. Forster comments that scholars will point to the erosion of this world-view in African society:

There can be no doubt that it would be naïve to assume that all Africans view the world in such an integrated manner. The effects of individualism, westernisation and the stigmatisation of African concepts of being have had a marked effect on the prominence of the African worldview (From modernising influences in schools, and from ignorant religious movements in Christianity and Islam, there has been a significant effect in the breakdown of traditional African patterns of thought and the resulting behaviour) ${ }^{7}$

Some critics have viewed Ubuntu as a post colonial prophetic illusion or utopian dream while others have depicted it as a purely Bantu philosophy not applicable to other tribes, Louw points that the Ubuntu emphasizes that consensus in both the social and political spheres can all too often be sidetracked into an oppressive form of collectivism or communalism, Schutte on the other hand, raises a philosophical point concerning the Ubuntu conception of individuality. In Ubuntu philosophy, the self is defined in terms of relationships with others causing Schutte to pose the question, "Can persons and personal relations really be equally primordial?" African thought addresses this contradiction by means of seriti or an energy force thought of as making both us and our relationships aspects of the same force field. In this way, both become primordial. However this does not do away with the objection as Schutte points out that, "in the perspective opened up by the African idea of the universe as a field of forces, it is difficult to see how the existing individual can have any enduring reality at all, much less how he can be possessed of the freedom and responsibility that is usually reckoned the most valuable mark of personhood."8 Nabudere speaks for many in welcoming the recovery of the Ubuntu philosophy praising its ability to provide for an African sense of identity and self respect to the degree that even the West is sitting up and taking notice as American Presidents and Secretaries of state begin to use the term. ${ }^{9}$ There can be no doubt as to the value of Ubuntu philosophy particularly in the field of reconciliation and in the settlement of disputes but doubts persist as to whether it is sufficiently rigorous to consistently enable the growth

\footnotetext{
${ }^{7}$ Ibid., 261.

${ }^{8}$ Schutte, op cit., 56.

9 Dani W. Nabudere, "Ubuntu Philosophy: Memory and Reconciliation," <http://www.grandslacs.net/doc/3621.pdf >, 29 September 2009.
} 


\section{THE CRISIS OF IDENTITY IN AFRICA}

of freedom and responsibility that Schutte identified as being the marks of personhood so necessary to face the crisis of identity in Africa today. A growth to personhood that is essential if the continent is to be transformed for the better. Even the proponents of Ubuntu admit to the distinct possibility of Ubuntu being derailed and abused thus becoming little more than an oppressive communalism.

In fact, any close examination of African culture and tradition will reveal the simple fact that all too often scant attention is paid to selfindividuation. The self is defined in relation to a larger social or ethnic group which encompasses not only the living but also the dead, the spirits, and the unborn. Even in contemporary African cities, the individual is not liberated from the bonds of the ethnic group for one's primary responsibility is to the clan or ethnic group, a situation inimical to self individuation. This lack of subjective becoming may be seen as a primary cause of many of the persistent and current problems besetting Africa. African thought requires a new emphasis on the development of subjectivity which, in turn, will permit self individuation. This approach holds out hope of a positive future for a troubled continent for it is only the mature and responsible subjects (persons) who can perceive, understand and make critical evaluations of their situations and then act responsibly.

\section{The Status of the Self in the African Way of Life and in Socio- Ethical Thought}

The status of the self in African socio-ethical thought is reflected in the communitarian features of social structures. This stems from the very essence of the African's cosmic vision which is not one where the universe is understood as something discrete and individuated but rather, it is conceived of as a series of interactions and interconnections. ${ }^{10}$ This general cosmic vision is particularly applicable in coming to an understanding of the relationship between self and community. Tempels captures the essence of such thinking when he points out that Bantu psychology cannot conceive of man as an individual, as a force existing by itself and apart from its ontological relationship with other living beings. Insisting on the sociality of the self, he states that "the Bantu cannot be a lone being." Further, he observes that for the Bantu, "every individual forms a link in a chain of vital forces, a living link, active and passive, joined from above to the ascending line of his ancestry and sustaining below the line of his descendants." 11 The outcome according to Senghor is that, "Negro-African society puts more stress on the group than on

\footnotetext{
10 According to the African cosmic vision, there are both visible and the invisible constituent parts of the universe. Life, in its totality, is conceived of as one "great chain of being" with things ontologically related to one another. The interactions and intercommunications between the visible created order and the invisible world of God, spirits and the ancestors are only possible when human beings become the ontological mean between entities acting above and below them.

${ }^{11}$ Placide Tempels, Bantu Pbilosophy (Paris: Presence Africaine, 1959), 108.
} 
the individual, more on solidarity than on activity and the needs of the individual, more on the communion of persons than on their autonomy."12 Mbiti in acknowledging the communal dimension of the African way of life states:

In traditional life, the individual does not and cannot exist alone except corporately. He owes this existence to other people, including those of past generations and his contemporaries. He is simply part of the whole. The community must therefore make, create, or produce the individual; for the individual depends on the corporate group ... whatever happens to the individual happens to the whole group, and whatever happens to the whole group happens to the individual. The individual can only say 'I am, because we are; and since we are therefore I am'. This is the cardinal point in the understanding of the African view of man. ${ }^{13}$

In acknowledging this, Nasseem states that the starting point of African epistemology should be the premise, "we are, therefore, I am." African philosophy is a collective mind and for the African, 'I' pre-supposes a 'We,' in fact ' $\mathrm{T}$ ' is contingent upon 'We."'14 Toure describes it even more forcefully stating that "Africa is fundamentally communocratic." 15

\section{African Communalism: Implications for the Subjectivity of the Self in}

Our overview of the relation between self and community in Africa has provided us some important insights. The ontological primacy of the community and the organic character of the relations between individual persons even beyond physical death both point to the all-importance of the community in enabling the individual to achieve well-being and realize selfhood. However, this self is defined in terms of the 'we existence' through social interactions.

Okolo observes, that such an understanding of the self is "bound to generate all sorts of problems with regard to the status of self as an individual, as an independent subject." 16 Though Gyekye in his moderate communitarian

\footnotetext{
12 Leopold Senghor, On African Socialism (London: Pall Mall Press, 1964), 93.

${ }_{13}^{13}$ John S. Mbiti, African Religions and Philosophy (Oxford: Heinemann, 1969), 108.

14 Zubairi 'b. Nasseem, "African Heritage and Contemporary Life: An Experience of Epistemological Change," in The Foundations of Social Life: Ugandan Philosophical Studies I (Washington, D. C: The Council for Research in Values and Philosophy, 1992), 20.

${ }^{15}$ Sekou Toure, Presence Africaine, 24 (1959), 25.

${ }^{16}$ Chukwudum B. Okolo, "Self as a Problem in African Philosophy," in International Philosophical Quarterly, 32:4 (December 1992), 483.
} 


\section{THE CRISIS OF IDENTITY IN AFRICA}

theory ${ }^{17}$ argues that individuality, autonomy and responsibility are to some extent respected and catered for in the African communalistic understanding, one cannot fail to notice that such assertions of individual freedom, autonomy and responsibility are rarely exercised owing to the authoritarian hierarchical structure and deep respect for tradition found within the African culture.

In his perceptive analysis of African communalism, Nze raises pertinent questions related to the issues of individual autonomy and freedom. A key question posed by Nze asks "how free is the individual in African communalism?" In seeking to answer this question Nze and many other authors seem to be content to believe that the individual is free even though his/her will is determined by the community. Nze states that, "although the individual is swallowed by the society in African communalism, he still enjoys his freedom and autonomy."18

This view is highly questionable, especially as the seeming freedom and autonomy which the individual enjoys are ultimately and in practical reality, derived from and determined by the cultural community. This leads Okolo to conclude that, "in African philosophy, self as a subject suffers; it is accounted for almost totally in terms of relation to others." 19 As a result it is the case that the existential situation in most African communities is that there is little or no room for individual values such as personal initiative, responsibility, subjectivity, spontaneity and self determination. These values are essential in the exercise of personal freedom and autonomy for each individual person has an intrinsic dimension to his/her being. A person cannot be reduced to a mere set of extrinsic relations. A person is a subject, not simply an object; an end in himself/herself and not simply a means. Being an individual subject, he/she is self-determined and not merely other-determined. In fact the very word 'autonomy' consists of two Greek words 'autos' meaning self and 'nomos' meaning rule; hence in the words of Okolo "to ignore or treat inadequately such values as personal initiative, responsibility, subjectivity, independence, etc ... is to undermine the very roots of human freedom and autonomy." 20

This is reflected in Kisekka's statement that the most pressing issue facing contemporary Africa, "is the lack of personal identity or personal selfdirection which reduces the individual to simply living instead of existing historically, culturally, and socially." 21 The effect of such a condition is the creation of a mentality that someone else cares for you more than you care for yourself, the mentality of a chronic hierarchical dependence on cultural community. Accordingly, many scholars who work on the contemporary

\footnotetext{
${ }^{17}$ Kwame Gyekye, Tradition and Modernity: Philosophical Reflections on the African Experience (Oxford: Oxford University Press, 1997), 35-61.

18 Chukwuemeka Nze, Aspects of African Communalism (Nigeria: Veritas Publishers, 1989), 20-23

${ }^{19}$ Okolo, op cit., 483.

${ }^{20}$ Ibid., 483.

${ }^{21}$ J. Kisekka, "The Destiny of the Individual in Contemporary Africa," in Ethics, Human Rights and Development in Africa: Ugandan Philosophical Studies III, ed. by A. T. Dalfovo (Washington: The Council for Research in Values and Philosophy, 2002), 69.
} 
African situation see a close connection between massive poverty, corruption, bad leadership, lack of sustainable development and prevalent growth of HIV/AIDS and the lack of recognition of self-hood as seen in excessive objectification or overdetermination of the cultural community. On this subject contemporary African philosophy is largely silent leading us to agree with Okolo in his conviction that, "African philosophy appears to suffer from a significant weakness or blind spot on this important aspect of the self."'22

We will now examine how the Kierkegaardian emphasis on 'subjective becoming' offers some significant insights to assist African philosophy to respond to the question of personal identity in Africa.

\section{The Application of Kierkegaardian Philosophy in the African Context}

Søren Kierkegaard, a nineteenth century philosopher, is renowned for his insistence on subjectivity and other concepts such as inwardness, passion, responsibility and character. He argued for the category of the 'single individual' and insisted on the subjectivity of the self against the totalizing Hegelian philosophy and against the "individual's submergence to a so-called "crowd". In developing subjectivity of the self in Africa, I believe, some essential and valuable insights from Kierkegaard, such as his concept of the 'single individual,' the task of becoming a subject and the critique of the crowd, are relevant if we are to address the problems of the African continent. In saying this, we find ourselves in agreement with the Universalistic current of African philosophy who argue that philosophy is not culture dependent but is rather a systematic and methodological inquiry that should never be altered according to geographical applications. ${ }^{23}$ One proponent of this line of thought is Bodunrin who argues that in the same way that Socrates and Plato were opposed to popular beliefs and opinions, so too, must African philosophy be opposed to traditional cultural beliefs and the popular folk behaviour. In Bodunrin's estimation philosophy is "criticism which irrational, impartial, and the articulate appraisal (of a proposition) whether positive or negative."24

Wiredu goes beyond Bodunrin as he sees the urgency of taking African thought a rightful place alongside the thought of other peoples of the world and argues that philosophy as an enterprise will not change in its essence or methodologies in the context of Africa; philosophy is universal. He argues that traditional culture should be recorded and then critically interpreted.

22 Okolo, op cit., 483.

23 Odera Oruka identifies four trends in contemporary African philosophy discourses. They are: Ethenophilosophy, Philosophical sagacity or Sage Philosophy, Nationalist-Ideological philosophy and Professional philosophy. In Professional philosophy there are different currents of thought such as the Universalist current of thought, Dialectical current of thought and Hermeneutical current of thought.

${ }^{24}$ Peter O. Bodunrin, "The Question of African Philosophy," in Sage Philosophy: Indigenous Thinkers and Modern Debate on African Philosophy, ed. by Henry Odera Oruka (Nairobi: African Centre for Technology Studies, 1991), 163. 


\section{THE CRISIS OF IDENTITY IN AFRICA}

Philosophical thinking is exemplified not in the mere recording of traditions and cultures, (the preoccupation of the influential African ethnophilosophers) but in the reconstruction of contemporary African culture. Thus, the main thrust of his philosophical thinking is nothing less than the attempt to lift the African philosophical enterprise by "due reflection" 25 and self-criticism to the universal level and then turn to the specific existential conditions and priorities of African social and political context, combining these in search of truth.

However, this process of due reflection and self criticism in search of truth presupposes a prior process of individuation. Hereby, the subject has succeeded in breaking free from the prison of collectivism and become a truly free and autonomous 'single individual' able to embark on this quest for the truth by undertaking a critical evaluation of contemporary African culture. It is to this prior process of individuation that insights gleaned from Kierkegaardian philosophy might be most fruitfully applied in the African context.

\section{The Kierkegaardian Philosophy of Subjectivity and its Essential Insights}

This concept of the 'single individual' is at the heart of Kierkegaard's anthropology and the basis of his social analysis, activating and explaining his acerbic critique of the age. Kierkegaard tells us repeatedly that, "this matter of the single individual is the most decisive thing."26 Throughout his oeuvre, Kierkegaard takes pains to convince his readers that existing as a responsible individual human being, is the first condition in achieving authentic selfhood.

Against the collectivizing power of his age, Kierkegaard, like Socrates, insists that a truly human existence as a single individual is something one must attain. It is not given with birth nor attained simply by growing older in a society but it is a way of living that one must choose to actualize in the face of all sorts of contrary inclinations and pressures. This process of bringing the individual to birth, Kierkegaard explains, is the task of subjectivity and it is essentially related to human existence demanding a constant striving towards inwardness. This process of becoming subjective is bound to the processes of decision and choice; for every day we make decisions which give content to our lives. It is precisely this ability to make choices and decisions that is stifled by the domination of the cultural community so contributing to the prevailing culture of dependency in Africa.

Kierkegaard argues that the most serious threat to subjectivity and individuation comes from what he calls the crowd. The crowd is none other than the untruth as opposed to the truth of individuation and subjectivity thereby precluding a truly human existence. By the crowd, Kierkegaard means

\footnotetext{
${ }^{25}$ Kwassi Wiredu, Cultural Universals and Particulars: An African Perspective (Indianapolis: Indiana University Press, 1996).

${ }^{26}$ Søren Kierkegaard, The Point of View for My Work as an Author, trans. by Walter Lowrie (New York: Oxford University Press, 1939), 122.
} 
not simply a group of people, an entity, but more fundamentally a mentality, a way of thinking and living. The consequence of this way of life as a member of the crowd is the loss of the self for, "to be different from the others would be the most fearful agony." 27 So powerful is this fear that in many cases one would rather die than differentiate oneself from the others in any decisive sense. Hence, in Kierkegaard's words, "no one in our day dares to be a person. The one is so afraid of 'the others' that he does not dare to be an 'I."'28 We may conclude without exaggeration that this is the present situation with regard to the status of the self in many African communities today.

The second characteristic of the crowd is the desire for ease. In the African context we see it manifest itself in the prevailing culture of dependency and paternalism that underpins corruption, dictatorship and the abuse of political and economic power. As Kierkegaard says it is easier to be a member of the crowd, but if this is the course we choose then there is a price to be paid. Out of fear or because of the desire for ease we abdicate the responsibility for our choices bowing to the dictates of the crowd. Yet it is this taking responsibility for our choices that defines and gives birth to self. It singles us out and makes it possible to have a genuine relation to the other. To Kierkegaard, it is the acceptance of this responsibility that marks the distinctive quality of human existence. Thus, in the crowd, one no longer measures oneself by the "prodigious measuring rod of ideal, but by the more meaningful standard of others." 29 The life of ease and avoidance of responsibility obscure the ideal and the voice of conscience and with no responsibility, conscience, inwardness or subjectivity, the person in the crowd is essentially "a number instead of a self." 30 Following a similar vein of thought, Buber observes that:

The person has become questionable through being collectivized ... The collectivity receives the right to hold the person who is bound to it in such a way that he ceases to have complete responsibility. The collectivity becomes what really exists, the person becomes derivatory ... Thereby the immeasurable value which constitutes man is imperilled. ${ }^{31}$

No wonder Kierkegaard is very passionate about subjectivity and defends the rights of the existing individual and his/her well-being against the collectivizing tendency of his age. However, insistence on subjectivity should

${ }^{27}$ Søren Kierkegaard, Journal and Papers, ed. and trans. by Howard V. Hong and Edna H. Hong, assisted by Gregor Malantschuk (Bloomington: Indiana University Press, 1967), no.1088.

28 Ibid., no.3219.

${ }^{29}$ Ibid., no. 4190 .

30 Søren Kierkegaard, The Sickness unto Death, trans. by Howard V. Hong and Edna H. Hong (Princeton: Princeton University Press, 1980), 33.

${ }^{31}$ Martin Buber, "The Question to the Single One," in Between Man and Man, trans. by Ronald Gregor Smith (London: Rutledge Classics, 2002), 80. 


\section{THE CRISIS OF IDENTITY IN AFRICA}

not be seen as Kierkegaard advocating some form of individualism nor is it the Enlightenment's political liberalism, featuring the individual as the bearer of natural rights against the power of the state. It is not Romanticism's expressivism, featuring the individual as creative genius unconstrained by rigid rules, whether they be aesthetic, moral, political or religious nor, is it, as Westphal says, "existentialism's metaphysical rebellion, featuring the individual as a courageous but lonely protest against a Godless, meaningless world." 32 Rather Kierkegaard is defending subjectivity on the grounds that it is in following the path of subjectivity that the individual accepts personal responsibility for the choice of a certain kind of life.

This implies that as one whose essence is to exist, in the sense of becoming subjective, the individual is essentially related both to God and to the neighbour. This point is crucial in that intersubjective (community) relations only become meaningful and authentic when one is capable of cultivating true subjectivity and this is what Africa requires at the present time. It is precisely at this point that we may begin to accomplish the task that Wiredu demands of the African philosopher, who, in his view, must combine insights derived from either east or west or both "with those gained from our own indigenous philosophical resources to create for ourselves" something from which all might learn. We have seen how Ubuntu philosophy, existing in the hyphen between the $I$ and the Thou, is thought of as being intersubjective yet in danger of becoming derailed by subsiding into an oppressive communalism that is so prevalent throughout the African continent.

Kierkegaard is concerned with the welfare of the singular individual, which he prioritized over the universal (the opposite of the established orthodoxy in Africa where primacy resides with the established tradition and laws of the tribe). By awarding primacy to the welfare of the single individual the existing being is brought to the point where he/she can evaluate the prevailing ethical, religious, social and cultural standards. Becoming ethically responsible is not a matter of adhering to or fulfilling the requirements of society or established customs alone, but of genuinely responding to the call of the singular other which is a prerequisite in realising the great strength of Ubuntu, that recognising the full humanity of the other. The most important question, then, for Kierkegaard, is one of 'relation': how does the individual relate to the truth? If the individual relates to the truth objectively, it amounts to empty conformism. However, if the individual relates to truth subjectively then he will critically question and examine the efficacy and merits of the prevailing social, cultural, religious and ethical currents, responsibility is accepted, conscience is awakened and personhood established. Now and only now may a genuine encounter with the other take place. Only now may the principles of Ubuntu become a living possibility. Only now can there be true intersubjectivity.

32 Merold Westphal, Becoming A Self: A Reading of Kierkegaard's Concluding Unscientific Postscript (Indiana: Purdue University Press, 1996), 140. 
The question of how an individual may cultivate the necessary subjectivity to enable him/her to genuinely engage with the problems of Africa while maintaining a true respect for the humanity of the other, is the issue to which we now turn our attention.

\section{Developing Subjectivity of the Self in Africa: Nguzo Tano}

Drawing on Afro-American tradition in order to address these questions, five principles (Nguro Tano) are identified as delineating the path of subjectivity. These constitute an ideological and conceptual revolt against the current African situation, particularly with regard to the status of the individual self. These provide certain means by which traditional African thought may be interrogated and critically evaluated so affirming its strengths while ensuring that it is not derailed into some form of oppressive collectivism.

The principle of kujichagulia represents self-determination and autonomy in other words, an internal transformation of the African self from within. The cultivation and practice of kujichagulia is fundamental for the exercise of personal freedom and to make responsible choices and decisions. It gives energy and orientation for self-transformation and internal development thus actualising the process of giving birth to responsible subjects. It will enable the African self to choose to individually make decisions previously determined by the collective and to manage his/her own affairs rather than accepting the dictates of the collective. This selfdetermination is the precondition necessary to grow as a responsible self. The development of an authentic and responsible self begins when the individual directs his/her energy inward, as Kierkegaard has shown. Without the cultivation of genuine subjectivity marked by self determination and autonomy, there will be no true progress in Africa.

The second marker of the path to subjectivity is the cultivation and practice of responsibility and conscience. The current situation in most African countries is the failure of the individual to take responsibility for his/her own life. Many individuals in Africa, including political leaders, live irresponsibly, paying very little attention to the voice of conscience and not following the path of inwardness thereby essentially living in the manner described by Kierkegaard, as 'a number instead of as a self.' One outcome is a widespread phenomenon that has gone deep into the fabric of African society. It is, as Dompere notes, "one of corruption, moral bankruptcy, visionary darkness, intellectual sterility and slave mentality." 33 For Africa to free herself from these evils requires its people must engage in the practice of uijmaa. Only when the individual self is able to cultivate a sound conscience, take responsibility for his/her decisions and life choices and live with a sense of accountability, fairness and transparency will Africa be securely on the road to development and progress.

${ }^{33}$ Kofi Kissi Dompere, Polyrbythmicity: Foundations of African Philosophy (London: Adonis \& Abbey Publishers Ltd., 2006), 119. 
The practice of the principles of self-determination, autonomy, responsibility and conscience will depend on the principle of Nia. Nia is a principle directed towards the realization of a vision where each individual self is able to determine and pursue their own goal. This goal should not be for selfish ends but must be concerned with the well-being of the individual self and that of the community. The cultivation of the principle of Nia is the interface between subjectivity and the community. In the terms used by Dion Foster Nia epitomises intersubjectivity representing the hyphen between the I and the Thou. The importance of this principle is that an individual's actions are purposefully directed towards the path of the creative process whereby undesirable political and socio-economic situations are transformed into new possibilities.

The Principle of Kuumba (Creativity): Kunmba is the outcome of the principle of Nia whereby the individual person's physical, mental and spiritual energies are harnessed for creative purposes. This principle is important in realising the latent creativity in the African made dormant by the overdetermination of the cultural community. The way forward is by developing new institutions and restructuring the existing institutions to encourage creative thinking and learning. Learning by merely mimicking other peoples' thinking systems and following traditions without critical examination demonstrates a lack of creativity whereas the consideration of new philosophies and then critically examining, adapting and assimilating valid elements from one's own culture and tradition is the essence of creativity, the creativity so important for the African continent today.

The Principle of Imani (Faith): The principle of Imani concerns the development of an attitude of confidence, self belief, optimism and hope. It is the hope of the tomorrow which never ends. The identity crisis that we have identified as currently existing in Africa has given rise to self-doubt and loss of creativity, courage, confidence and initiative. Imani comes as the result of empowerment, of giving to each African the opportunity to take responsibility themselves and their communities. It is this sense of empowerment that brings about a renewal creativity and self belief.

\section{Conclusion}

The widespread problems of Africa are largely attributable to the dislocation of its colonial past and the identity crisis this precipitated. Ethnophilosophers have addressed the problem of African identity by seeking to argue that it is derived from the community to which the individual belongs. This enterprise has not been without merit though its critics point to the fact membership of a community is, of itself, insufficient to enable individuation to take place while the oppressive communalism that is all too often the outcome may add to Africa's woes through the appearance of the worst features of what

Kierkegaard terms the crowd. However an important outcome of the work of the ethnophilosophers has been the renewal of the African philosophy of Ubuntu (humanness) which has recently come into focus, especially as a result 
of the political developments in South Africa. This rejuvenation of the philosophy of Ubuntu is important since it provides Africans with a sense of self-identity, self respect and achievement enabling them to deal with their problems in a positive manner by drawing on the humanistic values they have inherited, yet attention needs to be given to the elements of the ethics of Ubuntu in relation to the active engagement in horizontal relationships that shape who one is. True identity is not only based on the tasks or roles of the individuals.

It is precisely at this point that Kierkegaardian philosophy of subjectivity is able to offer a way since it is in following the path of subjectivity that the individual comes to accept personal responsibility for the choice of a certain kind of life. It is in following the path of subjectivity that personhood is achieved, the individual is able to respond authentically to the needs of the other and the true intersubjectivity that is Ubuntu's hallmark comes to fruition. This path of subjectivity may be mapped out in the African context by use of the five principles of kujichagulia, ujimaa, nia, kuumba, and imani. In this way the traditional culture may be critically interpreted so meeting the demands of Kwasi Wiredu to find a conjunction between African and Western Philosophies so lifting African philosophical enterprise to the universal level by means of "due reflection" so pointing the way forward to a brighter future for Africa as structures and institutions to promote individuation begin to be found.

Institute of Philosophy, Katholieke Universiteit Leuven, Belgium

\section{References}

Anta Diop, C., The African Origin of Civilization (Chicago: Lawrence Hill Books, 1974).

Buber, M., "The Question to the Single One," in Between Man and Man, trans. By Ronald Gregor Smith (London: Rutledge Classics, 2002).

Bodunrin, P. O., "The Question of African Philosophy," in Sage Philosophy: Indigenous Thinkers and Modern Debate on African Philosophy, ed. by Henry Odera Oruka (Nairobi: African Centre for Technology Studies, 1991).

Dompere, K. K., Polyrbythmicity: Foundations of African Philosophy (London: Adonis \& Abbey Publishers Ltd., 2006).

Forster, D., The impact of knowledge systems on buman development in Africa (Pretoria: University of South Africa, 2007).

Gyekye, K., Tradition and Modernity: Philosophical Reflections on the African Experience (Oxford: Oxford University Press, 1997).

Kierkegaard, S., The Point of View for My Work as an Author, trans. by Walter Lowrie (New York: Oxford University Press, 1939).

, Journal and Papers, trans. by Howard V. Hong and Edna H. Hong, assisted by Gregor Malantschuk (Bloomington: Indiana University Press, 1967). 


\section{THE CRISIS OF IDENTITY IN AFRICA}

, The Sickness unto Death, trans. Howard V. Hong and Edna H. Hong (Princeton: Princeton University Press, 1980).

Kisekka, J., "The Destiny of the Individual in Contemporary Africa," in Ethics, Human Rights and Development in Africa: Ugandan Philosophical Studies III (Washington: The Council for Research in Values and Philosophy, 2002).

Maathai, W., The Challenge for Africa: A New Vision (London: Heinemann, 2009).

Mbiti, J. S., African Religions and Philosophy (Oxford: Heinemann, 1969).

Nasseem, Z. "African Heritage and Contemporary Life: An Experience of Epistemological Change," in The Foundations of Social Life: Ugandan Philosophical Studies I (Washington, D. C: The Council for Research in Values and Philosophy, 1992).

Nze, C., Aspects of African Communalism (Nigeria: Veritas Publishers, 1989).

Ramose, B. M., African Philosophy Through Ubuntu (Harare: Mond Books,1999).

Senghor, L., On African Socialism (London: Pall Mall Press, 1964).

Shutte, A., Philosophy for Africa (Rondebosch, South Africa: UCT Press, 1993).

Tempels, P., Bantu Philosophy, trans. C. King (Paris: Presence Africaine, 1959).

Toure, Sekou, Presence Africaine, 24 (1959).

Tutu, D., No Future without Forgiveness: A Personal Overview of South Africa's Truth and Reconciliation Commission (London: Doubleday Publishers, 1999).

Westphal, M., Becoming A Self: A Reading of Kierkegaard's Concluding Unscientific Postscript (Indiana: Purdue University Press, 1996).

Wiredu, K., Cultural Universals and Particulars: An African Perspective. Indianapolis: Indiana University Press, 1996). 